\title{
SHIFTING CULTURE OF SEDULUR SIKEP SAMIN KARANGPACE INDIGENOUS COMMUNITY ON TOOL SYSTEMS AND LIVING EQUIPMENTS
}

\author{
Siti Qumariah \\ Bandung Polytechnic of Social Welfare (Poltekesos), Ir. H. Juanda Street (Dago), No. 367, \\ Bandung, sitiqumariah@,gmail.com \\ Theresia Martina Marwanti \\ Bandung Polytechnic of Social Welfare (Poltekesos), Ir. H. Juanda Street (Dago), No. 367 \\ Bandung, martina.wanti@,gmail.com
}

\begin{abstract}
This research was intended to obtain a picture of shifting or changing in cultural aspects in Sedulur Sikep Samin Karangpace, Klopoduwur Village, Banjarejo District, Blora Regency, Central Java Province. The cultural aspects research consists of religious or belief system, tool system and living equipments, knowledge system, as livelihood and aspect of social system. The research was conducted using a qualitative approach through descriptive method. The informants in this research were an Elder of Sedulur Sikep Samin Karangpace, a follower of Samin ideology, the head of RT 01 and four residents of Klopoduwur Village who could provide information related to cultural change. Data collection techniques were done through in-depth interviews, observation, triangulation and documentation study. This data was tested for validity through a credibility test. The research results showed that the cultural shift in the aspects of tool systems and living equipments has experienced considerable change, this was marked by changes in the use of tools or equipment currently in using. Tools and living equipments that originally came from nature changed into more modern equipments and in a modern way too.
\end{abstract}

Keywords:

Shifting Culture, Indigenous Community, Tool Systems and Living Equipments 